\title{
Bacterial communities in habitats of Dongchuan, China: Their role in slate weathering in triggering and flowing areas of debris flow
}

Qi Wang ( $\sim$ qiwang@nuist.edu.cn )

Nanjing University of Information Science and Technology https://orcid.org/0000-0003-3705-9922

Cheng Cheng

Nanjing University of Information Science and Technology

Evgenios Agathokleous

Nanjing University of Information Science and Technology

Shenggang Zang

Nanjing Agricultural University

Xiafang Sheng

Nanjing Agricultural University

\section{Research Article}

Keywords: Debris flow, Slate, Bacterial communities, Biodiversity, Bioweathering, Available calcium

Posted Date: April 15th, 2021

DOI: https://doi.org/10.21203/rs.3.rs-417585/v1

License: (9) This work is licensed under a Creative Commons Attribution 4.0 International License.

Read Full License 


\section{Abstract}

Debris flow is one of the most severe disasters in China's mountainous areas. Landslide soil materials are deposited on steep hill terrains or in channels and, once triggered by heavy rainfall, they can evolve into lethal debris flows. Some studies have suggested a prominent role of rock weathering in the formation of large landslides. In the present study, the a-diversity, composition, and weathering potential of bacterial communities inhabiting surfaces of slate rocks from the triggering area (altered less or more) and slate rocks from the flowing area of debris flows were studied. We found that a-diversity indices were positively correlated with the organic matter content, and Firmicutes accounted for about $66 \%$ of the total bacterial community. The variation in bacterial community composition was majorly driven by available $\mathrm{Ca}$. The highest relative abundances of genetic families associated with organic acid production, flagellar assembly and carbonic anhydrase were found in surfaces of less-altered slate rocks from the triggering area by using PICRUSt. All the bacterial strains isolated from rock surface have the ability to accelerate the weathering of slate, among which Pantoea and Pseudomonas genera showing the highest ability to enhance the dissolutions of $\mathrm{Fe}, \mathrm{Si}, \mathrm{Al}$, and $\mathrm{Ca}$ from slate. These results indicated an important role of the rock surface-inhabiting bacterial communities in the weathering of slate in both triggering and flowing areas of debris flow. This study also provides new insights into the biological characterizations of rocks in debris flow areas of Dongchuan, China.

\section{Introduction}

Debris flow is one of the most serious disasters in mountainous areas of China [1-2]. Due to the awareness of the risk of debris flows, studies concerning on the phenomenon and its potential consequences have received increasing attention [3]. However, there is hitherto no published study focusing on the biological characterization of rocks in debris-flow areas.

Considered as a natural museum of debris flow disasters, the Dongchuan district of Kunming city is one of the areas that suffered the most frequent and intense debris flows in China [4]. Within Dongchuan area, the exposures lithology is mainly composed of slate rocks. Being affected by tectonic movement and climatic factors for a long time, rocks in this region have suffered both chemical and physical weathering. Chemical weathering can change the chemical composition, textural, and mineralogical of rocks through oxidation and hydrolysis processes, reducing the strength of rocks [5]. So chemical weathering of rock may be more prone to slope failures, erosion, and landslides [6]. Landslide was considered one of the major triggers of the hill-slope debris flow in this area [7], where the weathered rock profiles provide abundant solid materials for the occurrence and development of debris flows [8].

Rocks can be considered primary ecosystems, on which only a few adapted microorganisms with rockweathering abilities can survive and grow [9]. Microbial communities have been documented to enhance rock and mineral weathering reactions [10-11] through oxidoreduction reactions, acidolysis and chelation reactions [12]. Furthermore, microbial adhesion, where bacterial flagella play an important role 
[13], contributes great contribute to biological weathering of minerals [14]. Carbonic anhydrase secreted by bacteria also plays a key role in mineral weathering [15].

Microbial communities have also been identified in various rocks [16], where they may facilitate the extraction of elements through bio-weathering [17-18]. Previous studies have suggested that microbial colonization on mineral surface was driven by surface charge, chemical property of rocks and mineral particles, and the local ecological niche [19-20]. Up to now, there is no published study investigating the diversity, composition, and ecological functions of bacterial communities inhabiting rocks with different alteration levels in debris flow areas.

Explaining the effects of rock mineralogy on bacterial communities' diversity, structure composition, and ecological functions related to rock condition greatly contributes to enhance the understanding of the role of bacterial communities in rock weathering [21]. In this study, rocks with different degrees of alteration from the triggering area and rocks from the flowing area of debris flow areas in Dongchuan district were collected for analyses of bacterial communities' diversity, structure composition, and rock-weathering functional potential by combining culture-independent and -dependent methods. We hypothesized that i) bacterial communities inhabiting rock surfaces in the debris flow areas are distinct from those inhabiting other rock ecosystems; ii) the $a$-diversity and composition of bacterial communities and the rockweathering potential vary among different groups; iii) the variation of bacterial communities may be driven by geochemical properties of rock samples. Our results add a new insight into the microbial communities inhabiting rock surfaces in debris flow areas and the specific functional groups involved in rock weathering, offering a perspective to advance the current understanding of the biological characteristics of debris flow.

\section{Materials And Methods}

\subsection{Site description and sample collection}

The rock samples were collected from the metamorphic slate deposit area $\left(20^{\circ} 14 \llbracket \mathrm{N}, 103^{\circ} 08 \llbracket \mathrm{E}\right)$ in Jiangjiagou valley (Dongchuan district, Kunming city, Yuannan province, China) in October 2014. Less altered and more altered rock samples (considered as LT group, and MT group, respectively) from triggering area, and rock samples from flowing area (considered as F group) were collected with sterilized shovels for comparison (Fig. S1). The weathering degrees of rocks were judged by visual observation. In particular, rock samples of LT group were obtained by striking the rock with sterilized hammers. Samples from each rock group were collected in triplicate (nine samples totally, each of which $600 \mathrm{~g}$; rock samples were $<2 \mathrm{~cm}$ in diameter). Then they were taken to the laboratory with dry ice and sieved $(2 \mathrm{~mm})$ within 48 $\mathrm{h}$ after collection. Samples for microbial DNA extraction were frozen at $-80^{\circ} \mathrm{C}$, while samples for chemical analysis and bacterial isolation were stored at $4^{\circ} \mathrm{C}$ within $24 \mathrm{~h}$.

\subsection{Geochemical analysis of rock samples}


Each rock sample was air-dried to measure $\mathrm{pH}$ and content of organic matter (OM) [22]. The contents of available elements (including $\mathrm{Al}, \mathrm{Si}, \mathrm{Ca}, \mathrm{Cu}, \mathrm{Fe}, \mathrm{K}, \mathrm{Mg}, \mathrm{Mn}$, and $\mathrm{Na}$ ) were determined by ICP-OES (Optimal 2100 DV, Perkin Elmer, USA) according to the method described by Huang et al. [22]. For details, see Supplementary Methods. For the analysis of mineral composition, the rock samples were ground to powder $(<150 \mu \mathrm{m})$ and detected by X-ray Diffraction (XRD) as described by Wang et al. [23]. In addition, analysis of particle size separation was conducted by applying wet sieving and centrifugation [23].

\subsection{DNA extraction and MiSeq sequencing}

Genomic DNA was extracted from $1 \mathrm{~g}$ rock samples with the Fast DNA® Spin kit soil (MP Biomedicals, Santa Ana, CA, USA). A bacteria-based primer set 515F/806R [24] was used to amplify about 300-bp fragments of the V4 hypervariable region of the bacterial 16S rRNA genes. PCR was performed according to the method described by Wang et al. [25]. Then, the high-throughput paired-end sequencing was performed with the Illumina MiSeq PE250 platform (Illumina, San Diego, CA).

\subsection{Isolation of bacterial strains and phylogenetic assignment}

The bacterial counts on rock surfaces were analyzed by using the sucrose-salts medium (SSM) according to the method described by Zhao et al. [21]. DNA extraction, PCR, and sequencing analysis of the obtained bacterial strains were conducted according to the method described by Huang et al. [22]. The resulting nucleotide sequences were analyzed by availing of the NCBI database to obtain the closest species match. Phylogenetic trees were constructed by the neighbor-joining method using the MEGA 4.0 software, and bacterial strains belong to the same genus was clustered into one branch.

\subsection{Rock weathering assays}

The rock-weathering potential experiment was performed according to the method described by Huang et al. [22]. The elemental composition of the slate rock was as follow: $\mathrm{SiO}_{2} 68.80 \%, \mathrm{Al}_{2} \mathrm{O}_{3} 16.20 \%, \mathrm{~K}_{2} \mathrm{O}$ $3.89 \%, \mathrm{Fe}_{2} \mathrm{O}_{3} 5.14 \%, \mathrm{CaO} 2.72 \%, \mathrm{MgO} 1.94 \%$, and $\mathrm{TiO}_{2}$ 0.76\%. Bushnell-Haas medium (BHm) was used to evaluate whether the bacteria could release $\mathrm{Si}, \mathrm{Al}, \mathrm{Fe}$, and $\mathrm{Ca}$ from slate under low-nutrient condition [23]. Sterilized BHm (containing slate) without incubation of bacterial strain was used as control to monitor the range of abiotic dissolution. After 7 days of incubation, $\mathrm{pH}$, and concentrations of $\mathrm{Si}, \mathrm{Al}, \mathrm{Fe}$, and $\mathrm{Ca}$ were determined by a pH meter and an ICP-OES, separately. Further details of the method are given in Supporting Materials.

\subsection{Statistical analyses}

The raw sequences of 16S rRNA gene MiSeq sequencing were processed on the i-Sanger platform (http://www.i-sanger.com/) as described by Wang et al. [25]. In order to avoid heterogeneity related to different sequencing depths, a randomly-selected subset of 11,000 sequences per sample was performed for down-stream analysis. Alpha diversity metrics studied were Shannon index [26], Chao 1 index [27], and Faith's PD [28]. PCoAwas employed to assess the variation in microbial community composition between samples These were followed by significance tests using ANOSIM [29] and PER-MANOVA [30]. In 
addition, bootstrapped trees were constructed using the UPGMA [31]. RDA was carried out to determine the effects of rock properties on the bacterial community in $\mathrm{R}$ using vegan. Possible correlation between bacterial community diversity, and rock properties was investigated by using the Spearman's correlation coefficient [32]. T-test was applied for significance testing. Potential differences in the rock properties, the a-diversity indices of bacterial communities, the $\mathrm{pH}$, and concentrations of elements in the cultural medium with incubation of bacterial strains from different groups were tested by using Tukey's HSD posthoc test by using SPSS v.21. The effects of bacterial genus on rock weathering were determined by ANOVA and Fisher's test at a threshold value of $a=0.05$.

PICRUSt, a computational approach [33] to predict the functional composition of a metagenome using marker gene data and a database of reference genomes, was also conducted on the i-Sanger platform to compare the potential ecological functions of bacterial communities among different groups. For details, see Supplementary Methods. In addition, functions associated with siderophore biosynthesis, carbonic anhydrase (CA) [15], flagellar assembly [13], and organic acid production [34] were selected as indicators of rock or mineral weathering potentials. Potential differences in the relative abundance of each rockweathering related functional category were also tested with Tukey's HSD post-hoc test.

\section{Results}

\subsection{Characterization of the rock samples}

As shown in Table 1, different patterns in available element content were found among different groups (Table 1). A significantly lower content of available Ca was found in group LT than in groups MT and F. All the rock samples had a relative alkaline $\mathrm{pH}$ (7.79 8.40). Based on the phase analysis of XRD, rock collected was found to be slate, and similar mineral constituents were found among these rock samples. The possible major mineral phases included 2:1 type clay minerals, kaolinite, biotite, and quartz (Fig S2). The proportion of gravel $(>2 \mathrm{~mm}$ ) was significantly higher in group LT than in groups MT and $F$, suggesting a lower alternation degree of rock samples of group LT (Supplementary Table S1). 
Table 1

Contents of available elements and organic matter, $\mathrm{pH}$, and cell number of slate rocks collected from less (LT group) and more altered rock samples (MT group)

from triggering area, and rock samples from flowing area of debris flow ( $F$ group). The values are arithmetic means \pm standard error $(n=3)$. Different letters represent significant differences within a row (i.e. among groups LT, MT, and F) according to Tukey's Honestly Significant Difference (HSD) post-hoc test $(P<$ $0.05)$.

\begin{tabular}{|llll|}
\hline \multicolumn{4}{|c|}{ Rock samples } \\
\cline { 2 - 4 } & LT & MT & F \\
\hline Available element content $\left(\mathrm{mg} \mathrm{kg}^{-1}\right)$ & & \\
\hline $\mathrm{Na}$ & $9.4 \pm 0.4 \mathrm{~b}$ & $9.0 \pm 0.5 \mathrm{~b}$ & $11.4 \pm 1.0 \mathrm{a}$ \\
\hline $\mathrm{Fe}$ & $112 \pm 5 \mathrm{a}$ & $92 \pm 3 \mathrm{~b}$ & $129 \pm 25 \mathrm{a}$ \\
\hline $\mathrm{Mg}$ & $394 \pm 26 \mathrm{~b}$ & $597 \pm 40 \mathrm{a}$ & $377 \pm 6 \mathrm{~b}$ \\
\hline $\mathrm{Al}$ & $524 \pm 41 \mathrm{a}$ & $244 \pm 8 \mathrm{~b}$ & $54 \pm 11 \mathrm{c}$ \\
\hline $\mathrm{K}$ & $60.5 \pm 2.7 \mathrm{~b}$ & $76.9 \pm 5.2 \mathrm{a}$ & $41.3 \pm 3.9 \mathrm{c}$ \\
\hline $\mathrm{Si}$ & $414 \pm 23 \mathrm{a}$ & $130 \pm 7 \mathrm{c}$ & $169 \pm 10 \mathrm{~b}$ \\
\hline $\mathrm{Mn}$ & $30.7 \pm 0.8 \mathrm{a}$ & $13.6 \pm 0.9 \mathrm{c}$ & $27.0 \pm 0.6 \mathrm{~b}$ \\
\hline $\mathrm{Ca}$ & $784 \pm 49 \mathrm{~b}$ & $2369 \pm 586 \mathrm{a}$ & $2295 \pm 143 \mathrm{a}$ \\
\hline Organic matter $\left(\mathrm{g} \mathrm{kg}^{-1}\right)$ & $3.19 \pm 0.15 \mathrm{a}$ & $0.75 \pm 0.05 \mathrm{c}$ & $2.67 \pm 0.21 \mathrm{~b}$ \\
\hline $\mathrm{pH}$ & $7.87 \pm 0.08 \mathrm{c}$ & $8.33 \pm 0.07 \mathrm{a}$ & $8.17 \pm 0.05 \mathrm{~b}$ \\
\hline Bacterial count $\left(\times 10^{5} \mathrm{cfu} \mathrm{g}^{-1}\right)$ & $15.2 \pm 1.8 \mathrm{a}$ & $5.1 \pm 1.3 \mathrm{~b}$ & $6.4 \pm 1.4 \mathrm{~b}$ \\
\hline
\end{tabular}

\subsection{Comparison of a-diversity and composition of bacterial communities among different rock samples.}

Totally, 123,379 high-quality sequences (11,662 - 15,258 for each sample) were obtained, with 275 genera belonging to 29 phyla, 92 classes, 134 orders, and 200 families. Firmicutes (accounting for about $66 \%$ of the total sequences), Proteobacteria (15\%), and Actinobacteria (11\%) were the three most dominant phyla.

Overall bacterial $a$-diversity indices exhibited significant differences ( $P<0.05$ in all cases, Tukey's test) (Fig. 1a). Collectively, the values of all the indices were highest in group LT, followed by groups $F$ and then MT, suggesting that the less alerted slate harbored a highera-diversity of bacterial communities 
UPGMA was used to compare the relatedness of bacterial communities based on the distribution of OTUs. The nine samples under investigation were divided into three groups, with group MT closely relating with those of group $F$ (Fig. 1c). These results are supported by the results of two-dimensional PCoA using Bray-Curtis similarity distances (Fig. 1b), unweighted unifrac distance (Fig. S3a), and weighted unifrac distance (Fig. S3b). The results were further confirmed by ADONIS and ANOSIM (Table S2).

At the phylum level, the relative abundances of Acidobacteria and Proteobacteria were highest in group LT, followed by groups F and then MT. The highest relative abundances of Chloroflexi and Firmicutes were found in group MT, followed by groups $F$ and then LT. The relative abundance of dominant taxa at class level also varied among rock samples from different sampling sites (Fig. 1c). The highest relative abundance of Bacilli was found in group MT, followed by groups F and then LT (Fig. 1d).

At genus level, 190, 125, and 172 genera were obtained from $L T, M T$, and F, respectively. The distribution of major bacterial genera (accounting for more than $0.25 \%$ of the total sequences) were presented in Table S3. Especially the ammonia oxidizing-related genus Nitrospira appeared significantly more abundant in group LT than in groups MT and F. Furthermore, Rhodobacter, Hydrogenophaga, and Limnobacterwere only observed in group $\mathrm{F}$ (Table S3).

Regarding OTU level, the exclusive and shared species-level OTUs among rock samples were inspected. The results showed that 281 out of 3,114 total OTUs (9.5\%) were shared among groups LT, MT, and F (Fig. 1e, left panel), accounting for $84.7 \%$ of all the sequences, indicating that these shared OTUs are mostly more abundant species. While OTUs unique to each group were mostly species with low abundance (Fig. 1e, right panel).

\subsection{Correlations between rock properties and bacterial community composition}

Rock properities (including contents of $\mathrm{Ca}, \mathrm{Mg}, \mathrm{Si}$, and $\mathrm{Mn}$ ) significantly correlated with the RDA model ( $P$ $<0.05$ ) were selected to analyze their respective influences on bacterial community composition (Fig. 2). RDA explained nearly $99 \%$ of the total variation in the rock bacterial community structure, with the first two axes explaining $93.13 \%$ of the variation (Fig. 2a). Rock bacterial communities formed similar clusters on the RDA plot (Fig. 2a), in agreement with PCoA analysis (Fig. 1b). Canonical variation partitioning revealed that the available Ca content was the major contributor of bacterial community variation, explaining $36.6 \%$ of the variation (Fig. 2b). The bacterial diversity indices were correlated negatively with available $\mathrm{Ca}$ and $\mathrm{Mg}$ contents $(r=-0.694 \sim-0.907)$ and positively with $\mathrm{Si}$ and Mn contents $(r=$ 0.760 0.973) of rock samples (Table S4). In addition, the diversity indices correlated positively with OM content $(r=0.795 \sim 0.913)$ and negatively correlated with $\mathrm{pH}(r=-0.932 \sim-0.913)$ of rock samples.

\subsection{Predicted microbial metabolic profiles}

Using PICRUSt, 28 of 43 level 2 KEGG Orthology groups (KOs) were represented by the data set, and 23 genetic families showed significant differences $(P<0.05)$ among groups LT, MT, and F (Fig. S4). As for 
the mineral weathering-related functional potential, the relative abundances of genetic families associated with organic acid production and flagellar assembly were highest in group LT, followed by groups F and then MT (Fig. 3). The highest relative abundance of CA was found in LT group. However, the relative abundance of genetic families involved in siderophore biosynthesis in groups MT and F was significantly higher than that of group LT. Collectively, these results indicate that the bacterial communities may influence the rock weathering through a variety of mechanisms in the rock environments.

\subsection{Rock weathering assays}

On the rock surfaces, $10^{5}-10^{6}$ bacterial counts per gram of rock were obtained. Furthermore, cultivable bacterial counts in group LT were significantly higher than those in groups MT and F (Table 1). Totally, 248 bacterial strains were obtained, of which 90,81 and 77 strains from LT, MT and F groups, respectively. Dissolved $\mathrm{Fe}, \mathrm{Si}, \mathrm{Al}$, and $\mathrm{Ca}$ from slate was used as an overall indicator of rock weathering. It was found that all the strains can enhance slate weathering compared with the uninoculated control (Table 2, TableS6). As shown in Fig. 4, the ratios of active Fe, Al, and Si solubilizers were significantly higher in group LT than in groups MT and F. The proportion of active Fe solubilizer was significantly higher in group F than group MT (Fig. 4b). No significant difference in the ratio of active Ca was found among different rock samples (Fig. 4f).

Table 2

Influence of bacteria isolated from slate rock samples on the element releases from slate. The values are arithmetic means \pm standard error $(n=3)$. Different superscript letters represent significant differences within a row (i.e. among groups LT, MT, and F) according to Tukey's Honestly Significant Difference (HSD) post-hoc test $(P<0.05)$.

\begin{tabular}{|c|c|c|c|c|c|c|c|}
\hline \multirow[t]{2}{*}{$\begin{array}{l}\text { Rock } \\
\text { sample }\end{array}$} & \multicolumn{4}{|c|}{ Concn. range $(\mu \mathrm{M})$ of element released ${ }^{a}$} & \multicolumn{3}{|c|}{$\begin{array}{l}\text { Ratio of acid (or alkali)-producing } \\
\text { bacteria (\%) by pH }\end{array}$} \\
\hline & $\mathrm{Fe}$ & Si & Al & $\mathrm{Ca}$ & $<4$ & $4-7$ & $>7$ \\
\hline LT & $3.7-105$ & $104-211$ & $5.2-82$ & $372-2667$ & $2.5 \pm 0.3^{c}$ & $15 \pm 2.1^{a}$ & $82 \pm 1.2^{\mathrm{a}}$ \\
\hline MT & $3.3-44$ & $103-144$ & $3.7-12$ & $526-2437$ & $12 \pm 1.9^{b}$ & $3.3 \pm 0.3^{c}$ & $84 \pm 2.4^{\mathrm{a}}$ \\
\hline $\mathrm{F}$ & $3.4-47$ & $104-150$ & $4.0-46$ & $707-3572$ & $26 \pm 2.6^{a}$ & $9.0 \pm 1.2^{b}$ & $65 \pm 5.6^{b}$ \\
\hline
\end{tabular}

Based on the distribution of the concentrations of $\mathrm{Fe}, \mathrm{Si}, \mathrm{Al}$, and $\mathrm{Ca}$ in cultural medium in the presence or absence of bacterial strains (Table S6), these strains could be grouped into the following three categories: strains with poor rock-weathering potential $(<5 \mu \mathrm{M} \mathrm{Fe},<8 \mu \mathrm{M} \mathrm{Al},<110 \mu \mathrm{M} \mathrm{Si}$, and $<800 \mu \mathrm{M} \mathrm{Ca}$ in the culture), moderate rock-weathering potential (5-10 $\mu \mathrm{M} \mathrm{Fe}, 8-10 \mu \mathrm{M} \mathrm{Al}, 110-120 \mu \mathrm{M} \mathrm{Si}$, and 800-1000 
$\mu \mathrm{M} \mathrm{Ca}$ ), and high rock-weathering potential ( $>10 \mu \mathrm{M} \mathrm{Fe},>1 \mu \mathrm{M} \mathrm{Al},>120 \mu \mathrm{M} \mathrm{Si}$, and $>1000 \mu \mathrm{M} \mathrm{Ca})$. As shown in Fig. 4, the proportion of highly active $\mathrm{Fe}, \mathrm{Al}$, and $\mathrm{Si}$ solubilizers was highest in group $\mathrm{F}$, followed by groups LT and then MT. The proportion of highly active Ca solubilizer in groups LT and F was significantly higher than that in group $\mathrm{MT}$, and no significant difference was found between groups $\mathrm{E}$ and F (Fig. 4f). Collectively, the rock weathering potential of slate-weathering bacteria form groups $L T$ and $F$ was higher than mineral-weathering bacteria from group MT.

The $\mathrm{pH}$ in the culture medium ranged from 3.21 to 8.76 in the presence of different bacterial strains (Table 2, Table S6). Most of the bacterial strains (about $78 \%$ ) showed high alkaline pH values. The ratio of highly $(\mathrm{pH}<4)$ active acid-producing strains was highest in group F, followed by groups MT and LT. In addition, the proportion of the alkaline-producing $(\mathrm{pH}>7)$ strains in groups LT and MT was higher than group $F$.

\subsection{Linking of culturable bacterial taxonomy with their rock weathering potential}

As shown in Fig. 5, the rock-weathering bacterial strains were affiliated with 14 genera $(8,7$ and 8 genera were obtained from groups LT, MT and F, respectively). Bacterial strains assigned to Pseudarthrobacter ( $n$ $=129)$, Arthrobacter $(n=11)$, and Bacillus $(n=59)$ were common in the rock samples. Strains belonging to Microbacterium $(n=2)$ and Sphingomonas $(n=4)$ were detected in both LT and MT groups, and Pseudomonas $(n=18)$ was found in both MT and F groups. Furthermore, each group had its unique genera (Fig. 5a)

The relative activity of solubilizing $\mathrm{Fe}, \mathrm{Al}, \mathrm{Si}$, and $\mathrm{Ca}$ from slate were compared among different genera (with a minimum of 3 strains for each genus). As shown in Fig. 5b, representatives of Pantoea and Pseudomonas exhibited considerably higher activities promoting the release of $\mathrm{Fe}, \mathrm{Al}, \mathrm{Si}$, and $\mathrm{Ca}$ from slate, compared with other genera. The medium pH of Pantoea $(4.41 \pm 1.96)$ and Pseudomonas (4.95 \pm 1.94) strains was significantly lower than that of other genera. In addition, $\mathrm{pH}$ showed negative correlations with Fe, Al, and Ca released from slate $(r=-0.824 \sim-0.876)$.

When inter-comparing the taxonomic data obtained from the cultivation-dependent and -independent methods, 4 of the 25 most abundant bacterial genera identified through 16S rRNA gene Miseq sequencing ( $19 \%$ of total sequences) were also identified by the cultivation-dependent method (Table S3). Most of the cultured genera with rock-weathering potential were also detected by the cultureindependent method, except for Pesudarthrobacter, Micrococcus, Terrabacter, Ensifer, Pantoea, and Enterobacter (Fig. 5a). Generally, the cultivable rock-weathering bacterial genera took up a small proportion of the bacterial community detected by cultivable-independent method.

\section{Discussion}

Phylogenetic analyses revealed diverse and distinct bacterial communities in diverse ecosystems [19]. Our study also showed distinct and diverse bacterial communities inhabiting slate surface [35-37]. 
Especially, Firmicutes was the most dominant phylum identified in this study, ranging from $34-83 \%$ of the total bacterial communities. According to previous studies, abundant Firmicutes was found in soil and aquatic environments, as well as in the anaerobic digestion processes where they play an important role in the decomposition and recycling of organic matters [38]. In the present study, Bacillus, belonging to Firmicutes, was found to be one of the most abundant genera by both cultivation-dependent and independent methods in the studied area. Previous studies detected Bacillus in various rocks and soils $[23,36,39]$, possibly be due to their key role in biological control of pathogenic fungal growth, enzymes used in agriculture and industry, mineralization of organic matter, plant growth promotion, and rock weathering. Based on the investigation of bacterial communities in rock cores of common limestonemudstone alterations, Lazar et al. [40] suggested that Bacillus originate from the forest soils and are most likely feeding labile organic matter inputs in the rock matrix.

Previous studies have documented that changes in limited nutrient substrates (including $\mathrm{Ca}, \mathrm{Mg}, \mathrm{P}, \mathrm{K}, \mathrm{Si}$, and $\mathrm{Al}$ ) can cause variation of bacterial communities inhabiting rock surface [35, 37, 39]. Especially, the presence of limited nutrients in rocks can render rocks attractive to preferential colonization by microbiota with different composition [41]. Consistent with previous studies, available Ca content in the slate rocks was found to be the major driver of variations in bacterial community structure. As an essential nutrient for living organisms, Ca is involved in bacterial growth and metabolism processes, including heat shock, chemotaxis, differentiation, and cell cycle [37]. Sridevi et al. [42] also found that the addition of Ca significantly shifted the composition of soil bacterial communities in a deciduous secondgrowth forest, and affected the relative abundance of hundreds of bacterial taxa. In this study, the available Ca content correlated negatively with the $\alpha$-diversity indices. Similarly, Groffman et al. [43] found that $\mathrm{Ca}$ addition led to a lower microbial $\mathrm{N}$ biomass in a northern hardwood forest. Besides, Kalwasińska et al. [37] found that the number of OTUs in the salino-alkaline lime was positively correlated with the $\mathrm{Ca}$ concentration. The discrepancy in findings may be contributed to the unique microhabitats the bacterial communities occupied. In addition, the $a$-diversity indices also positively correlated with the content of OM in this study. Kirtzel et al. [44] found that the weathering of black slate resulted in the degradation of $\mathrm{OM}$ and the release of organic chemical compounds when exposed to oxygen. A similar phenomenon was found inour study, where the OM content in the less altered slates was significantly higher than that in more altered slate rocks.

In order to evaluate the rock weathering potential and the involved mechanisms of the bacterial communities, we analyzed both the relative abundance of the weathering-related gene functional category with PICRUST and the effects of bacterial strains on the release of structural elements from slate from different groups with cultivation method. The PICRUST results suggest that the bacterial communities may influence the rock weathering through a variety of mechanisms among different sites. Based on the cultivation-dependent method, it was found the surface bacterial communities may play an important role in slate weathering. Furthermore, distinct bacterial rock-weathering effectiveness and phenotypes were observed among the different groups based on the element release patterns of the bacteria (Table 2, Table S6), which might be affected by the sample-specific characteristics (Tables 1, Fig. 
S2). Previous studies have suggested that the weathering effectiveness and phenotypes were dependent on the bacterial populations and their origin [22].

In the present study, acidolysis was considered as the major mechanism involved in slate weathering for both Pantoea and Pseudomonas genera, which have also been documented to accelerate the weathering of $\mathrm{K}$ feldspar, biotite, apatite, smectite, and granite through the production of organic acids and siderophores, as well as pilus formation [34, 45-46]. However, in this study about $78 \%$ of the slateweathering bacterial strains could alkalize the medium. Alkalization is one of the mechanisms involved in mineral weathering [47]. Kisiel et al. [48] found that glauconite weathered to form pseudomorphs of goethite, which was possibly due to the alkaline $\mathrm{pH}$ of the environment caused by the high calcite content. During the microbial weathering of calcite, Dou and Lian [49] found that in the presence of rockinhabiting fungal strain $\mathrm{pH}$ in the cultural medium decreased from 7 to 6.8 within $24 \mathrm{~h}$ and then increased to 7.8 within 32 to $56 \mathrm{~h}$, and production of acetic acid was considered as the major mechanism involved in the weathering of calcite. Considering the practical constrains of time and resources for inducing the release of the elements from the slate by 248 bacterial strains, a deeper insight into the analysis of metabolites of bacterial strains during their bio-weathering of slate needs to be further considered in the future.

\section{Conclusion}

By combining cultivation-dependent and -independent approaches, this study demonstrates for the first time that slate rock surfaces were inhabited by diverse and distinct bacterial communities with slateweathering potential in both triggering and flowing areas of debris flow. The $\alpha$ - diversity indices positively correlated with the content of OM of rock samples, and the less altered slated collected from the triggering area had the highest diversity indices. Our study found that the content of available Ca was the major driver of the variation in bacterial community structures among the slate rocks of different groups, with Firmicutes being the most abundant bacterial phylum. The culture-dependent analysis suggested that all the bacterial strains could accelerate the weathering of slate, among which Pantoea and Pseudomonas genera showed the highest effectively ability to enhance the dissolution of $\mathrm{Fe}, \mathrm{Si}$, $\mathrm{Al}$, and Ca from slate.

\section{Declarations}

Acknowledgments We want to thank the graduate students and staff involved in collecting rock sampling.

Funding This work was supported by the Chinese National Natural Science Foundation (41977040, 41473075) and the Startup Foundation for Introducing Talent of Nanjing University of Information Science \& Technology (NUIST), Nanjing, China (No. 003027 and No. 003080). 
Data Availability Miseq sequencing data were uploaded to the European Nucleotide Archive under the accession number PRJNA690661. The obtained nucleotide sequences of partial bacterial 16S rRNA genes of cultural bacterial strains have been uploaded to the European Nucleotide Archive under accession numbers from JX848973 to JX849123.

Code availability Yes.

Declaration of Interest: Authors declare that there is no conflict of interest.

Ethics Approval Not applicable.

Consent to participate Yes.

Consent for publication Yes.

\section{References}

1. Jakob M, Hungr O (2015) Introduction. In: Jakob M, Hungr O (eds) Debris-flow hazards and related phenomena. Springer-Praxis, Chichester, pp 1-7. 2005

2. Zhang SC (1993) A comprehensive approach to the observation and prevention of debris flows in China. Nat Hazards 7:1-23. https://doi.org/10.1007/BF00595676

3. Dowling CA, Santi PM (2014) Debris flows and their toll on human life: a global analysis of debrisflow fatalities from 1950 to 2011. Nat Hazards 71:203-227. https://doi.org/10.1007/s11069-0130907-4

4. Ding M, Wei F, Hu K (2012) Property insurance against debris-flow disasters based on risk assessment and the principal-agent theory. Nat Hazards 60:801-817. https://doi.org/10.1007/s11069-011-9897-2

5. Che VB, Fontijn K, Ernst GGJ, Kervyn M, Elburg M, Ranst EV, Suh CE (2012) Evaluating the degree of weathering in landslide-prone soils in the humid tropics: the case of Limbe, SW Cameroon. Geoderma 170:378-389. https://doi.org/10.1016/j.geoderma.2011.10.013

6. Regmi AD, Yoshida K, Dhital MR, Pradhan B (2014) Weathering and mineralogical variation in gneissic rocks and their effect in Sangrumba Landslide, East Nepal. Environ Earth Sci 71:27112727. https://doi.org/10.1007/s12665-013-2649-8

7. Chen HX, Zhang LM, Chang DS, Zhang S (2012) Mechanisms and runout characteristics of the rainfall-triggered debris flow in Xiaojiagou in Sichuan Province, China. Nat Hazards 62:1037-1057. https://doi.org/10.1007/s11069-012-0133-5

8. Cui K, Wu G, Wang X, Chen W, Lu H (2016) Research on the behavior and mechanism of the slate from the slope at the gully of debris flow respond to climate environment. Chinese J Rock Mech Eng 35:2944-2952. https://doi.org/10.13722/j.cnki.jrme.2014.1712 
9. Uroz S, Calvaruso C, Turpault MP, Frey-Klett P (2009) Mineral weathering by bacteria: ecology, actors and mechanisms. Trends Microbiol 17:378-387. https://doi.org/10.1016/j.tim.2009.05.004

10. Esposito A, Ciccazzo S, Borruso L, Zerbe S, Daffonchio D, Brusetti L (2013) A three-scale analysis of bacterial communities involved in rocks colonization and soil formation in high mountain environments. Curr Microbiol 67:472-479. https://doi.org/10.1007/s00284-013-0391-9

11. Santelli CM, Welch SA, Westrich HR, Banfield JF (2001) The effect of Fe-oxidizing bacteria on Fesilicate mineral dissolution. Chem Geol 180:99-115. https://doi.org/10.1016/S0009-2541(01)003084

12. Balland C, Poszwa A, Leyval C, Mustin C (2010) Dissolution rates of phyllosilicates as a function of bacterial metabolic diversity. Geochim Cosmochim Acta 74:5478-5493. https://doi.org/10.1016/j.gca.2010.06.022

13. Wang YL, Li L, Sun Y, He LY, Sheng XF (2020a) Impact of the fliF gene on biotite weathering of Rhizobium pusense S41. Geomicrobiol J 37:308-314. https://doi.org/10.1080/01490451.2019.1697396

14. Chen W, Luo L, He LY, Wang Q, Sheng XF (2016) Distinct mineral weathering behaviors of the novel mineral-weathering strains Rhizobium yantingense $\mathrm{H} 66$ and Rhizobium etli CFN42. Appl Environ Microbiol 82:4090-4099. https://doi.org/10.1128/AEM.00918-16

15. Xiao LL, Lian B, Hao JC, Liu CQ, Wang SJ (2015) Effect of carbonic anhydrase on silicate weathering and carbonate formation at present day $\mathrm{CO}_{2}$ concentrations compared to primordial values. Sci Rep 5:7733. https://doi.org/10.1038/srep07733

16. Olsson-Francis K, Simpson AE, Wolff-Boenisch D, Cockell CS (2012) The effect of rock composition on cyanobacterial weathering of crystalline basalt and rhyolite. Geobiology 10:434-444. https://doi/10.1111/j.1472-4669.2012.00333.x

17. Matlakowska R, Skłodowska A, Nejbert K (2012) Bioweathering of Kupferschiefer black shale (ForeSudetic Monocline, SW Poland) by indigenous bacteria: implication for dissolution and precipitation of minerals in deep underground mine. FEMS Microbiol Ecol 81:99-110. https://doi/10.1111/j.15746941.2012.01326.x

18. Zhao F, Qiu G, Huang Z, He LY, Sheng XF (2013) Characterization of Rhizobium sp. Q32 isolated from weathered rocks and its role in silicate mineral weathering. Geomicrobiol J 30:616-622. https://doi.org/10.1080/01490451.2012.746406

19. Calvaruso C, Turpault MP, Frey-Klett P(2006) Root-associated bacteria contribute to mineral weathering and to mineral nutrition in trees: a budgeting analysis. Appl Environ Microbiol 72: 12581266. https://doi.org/10.1128/AEM.72.2.1258-1266.2006

20. Lapanje A, Wimmersberger C, Furrer G, Brunner I, Frey B (2012) Pattern of elemental release during the granite dissolution can be changed by aerobic heterotrophic bacterial strains isolated from damma glacier (central Alps) deglaciated granite sand. Microb Ecol 63:865-882. https://doi.org/10.1007/s00248-011-9976-7 
21. Colin Y, Nicolitch O, Turpault MP, Uroz S (2017) Mineral types and tree species determine the functional and taxonomic structures of forest soil bacterial communities. Appl Environ Microbiol 83:e02684-e02616. https://doi.org/10.1128/AEM.02684-16

22. Huang J, Sheng XF, Xi J, He LY, Huang Z, Wang Q, Zhang ZD (2014) Depth-related changes in community structure of culturable mineral weathering bacteria and in weathering patterns caused by them along two contrasting soil profiles. Appl Environ Microbiol 80:29-42. https://doi.org/10.1128/AEM.04211-13

23. Wang Q, Cheng C, He LY, Huang Z, Sheng XF (2014) Characterization of depth-related changes in bacterial communities involved in mineral weathering along a mineral-rich soil profile. Geomicrobiol J 31:431-444. https://doi.org/10.1080/01490451.2013.848248

24. Hugerth LW, Wefer HA, Lundin S, Jakobsson HE, Lindberg M, Rodin S, Engstrand L, Andersson AF (2014) DegePrime, a program for degenerate primer design for broad-taxonomic-range PCR in microbial ecology studies. Appl Environ Microbiol 80:5116-5123. https://doi.org/10.1128/AEM.01403-14

25. Wang Q, Li ZZ, Li XW, Pin Q, Yuan XY, Agathokleous E, Feng ZZ (2021) Interactive effects of ozone exposure and nitrogen addition on the rhizosphere bacterial community of poplar saplings. Sci Total Environ 754:142134. https://doi.org/10.1016/j.scitotenv.2020.142134

26. Izsak J (2007) Parameter dependence of correlation between the Shannon index and members of parametric diversity index family. Ecol Indic 7:181-194.

https://doi.org/10.1016/j.ecolind.2005.12.001

27. Chao A (1984) Nonparametric-estimation of the number of classes in a population. Scand J Stat 11:265-270. https://www.jstor.org/stable/4615964

28. Faith DP (1992) Conservation, evaluation, and phylogenetic diversity. Biol Conserv 61:1-10. https://doi.org/10.1016/0006-3207(92)91201-3

29. Ramírez C, Romero J (2017) The microbiome of Seriola lalandi of wild and aquaculture origin reveals differences in composition and potential function. Front Microbiol 8:1844. https://doi.org/10.3389/fmicb.2017.01844

30. Pärnänen K, Karkman A, Hultman J, Lyra C, Bengtsson-Palme J, Larsson DGJ, Rautava S, Isolauri E, Salminen S, Kumar H, Satokari R, Virta M (2018) Maternal gut and breast milk microbiota affect infant gut antibiotic resistome and mobile genetic elements. Nat Commun 9:3891. https://doi.org/10.1038/s41467-018-06393-w

31. Caporaso JG, Bittinger K, Bushman FD, DeSantis TZ, Andersen GL, Knight R (2010) PyNAST: a flexible tool for aligning sequences to a template alignment. Bioinformatics 26:266-267. https://doi.org/10.1093/bioinformatics/btp636

32. Sun R, Zhang XX, Guo X, Wang D, Chu H (2015) Bacterial diversity in soils subjected to long-term chemical fertilization can be more stably maintained with the addition of livestock manure than wheat straw. Soil Biol Biochem 88:9-18. https://doi.org/10.1016/j.soilbio.2015.05.007 
33. Langille MGI, Zaneveld J, Caporaso JG, McDonald D, Knights D, Reyes JA, Clemente JC, Burkepile DE, Thurber RLV, Kbight R, Beiko RG, Huttenhower C (2013) Predictive functional profiling of microbial communities using 16S rRNA marker gene sequences. Nat Biotechnol 31:814-821. https://doi.org/10.1038/nbt.2676

34. Wang YL, Sun LJ, Xian CM,. Kou FL, Zhu Y, He LY, Sheng XF (2020b) Interactions between biotite and the mineral-weathering bacterium Pseudomonas azotoformans F77. Appl Environ Microbiol 86:e02568-e02519. https://doi.org/10.1128/AEM.02568-19

35. Choe YH, Kim M, Woo J, Lee MJ, Lee JI, Lee EJ, Lee YK (2018) Comparing rock-inhabiting microbial communities in different rock types from a high arctic polar desert. FEMS Microbiol Ecol 94:fiy070. https://doi.org/10.1093/femsec/fiy070

36. Wang Q, Ma GY, He LY, Sheng XF (2011) Characterization of bacterial community inhabiting the surfaces of weathered bricks of Nanjing Ming city walls. Sci Total Environ 409:756-762. https://doi.org/10.1016/j.scitotenv.2010.11.001

37. Kalwasińska A, Deja-Sikora E, Szabó A, Felföldi T, Kosobucki P, Brzezinska MS, Walczak M (2018) Salino-alkaline lime of anthropogenic origin a reservoir of diverse microbial communities. Sci Tol Environ 655:842-854. https://doi.org/10.1016/j.scitotenv.2018.11.246

38. Seong CN, Kang JW, Lee JH, Seo SY, Woo JJ, Park C, Bae KS, Kim MS (2018) Taxonomic hierarchy of the phylum Firmicutes and novel Firmicutes species originated from various environments in Korea. J Microbiol 56:1-10. https://doi.org/10.1007/s12275-018-7318-x

39. Tang J, Tang XX, Qin YM, He QS, Yi Y, Ji ZL (2019) Karst rocky desertification progress: Soil calcium as a possible driving force. Sci Total Environ 649:1250-1259.

https://doi.org/10.1016/j.scitotenv.2018.08.242

40. Lazar CS, Lehmann R, Stoll W, Rosenberger J, Totsche KU, Küsel K (2019) The endolithic bacterial diversity of shallow bedrock ecosystems. Sci Total Environ 679:35-44. https://doi.org/10.1016/j.scitotenv.2019.04.281

41. Carson JK, Campbell L, Rooney D, Clipson N, Gleeson DB (2009) Minerals in soil select distinct bacterial communities in their microhabitats. FEMS Microbiol Ecol 67:381-388. https://doi.org/10.1111/j.1574-6941.2008.00645.x

42. Sridevi G, Minocha R, Turlapati SA, Goldfarb KC, Brodie EL, Tisa LS, Minocha SC (2012) Soil bacterial communities of a calcium-supplemented and a reference watershed at the Hubbard Brook Experimental Forest (HBEF), New Hampshire, USA. FEMS Microbiol Ecol 79:728-740. https://doi.org/10.1111/j.1574-6941.2011.01258.x

43. Groffman PM, Fisk MC, Driscoll CT, Likens GE, Fahey TJ, Eagar C, Pardo LH (2006) Calcium additions and microbial nitrogen cycle processes in a northern hardwood forest. Ecosystems 9:1289-1305. https://doi.org/10.1007/s10021-006-0177-z

44. Kirtzel J, Ueberschaar N, Deckert-Gaudig T, Krause K, Deckert V, Gadd GM, Kothe E (2020) Organic acids, siderophores, enzymes and mechanical pressure for black slate bioweathering with the 
basidiomycete Schizophyllum commune. Environ Microbiol 22:1535-1546.

https://doi.org/10.1111/1462-2920.14749

45. Feng MH, Ngwenya BT, Wang L, Li WC, Olive V, Ellam RM (2011) Bacterial dissolution of fluorapatite as a possible source of elevated dissolved phosphate in the environment. Geochim Cosmochim Acta 75:5785-5796. https://doi.org/10.1016/j.gca.2011.07.019

46. Wongfun N, Plotze M, Furrer G, Brandl H (2014) Weathering of granite from the damma glacier area: The contribution of cyanogenic bacteria. Geomicrobiol J 31:93-100. https://doi.org/10.1080/01490451.2013.802396

47. Brehm U, Gorbushina A, Mottershead D (2005) The role of microorganisms and biofilms in the breakdown and dissolution of quartz and glass. Palaeogeogr Palaecol 219:117-129. https://doi.org/10.1016/B978-0-444-52019-7.50011-5

48. Kisiel M, Skiba M, Skoneczna M, Maj-Szeliga K, Błachowski A (2018) Weathering of glauconite in an alkaline environment - A case study from Krakow area, Poland. Catena 171:541-551. https://doi.org/10.1016/j.catena.2018.08.003

49. Dou C, Lian B (2009) Microbial weathering of calcite by rock-inhabiting fungi. Acta Mineralogica Snica 29:387-392. https://doi.org/10.1016/S1874-8651(10)60080-4

\section{Figures}


(a)
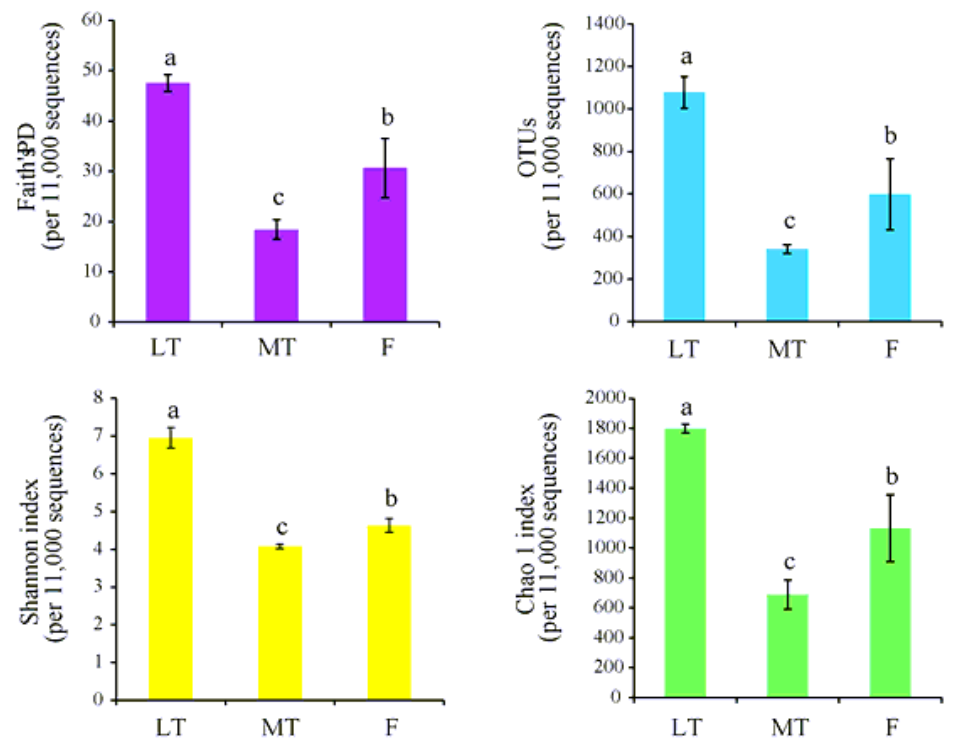

(b)

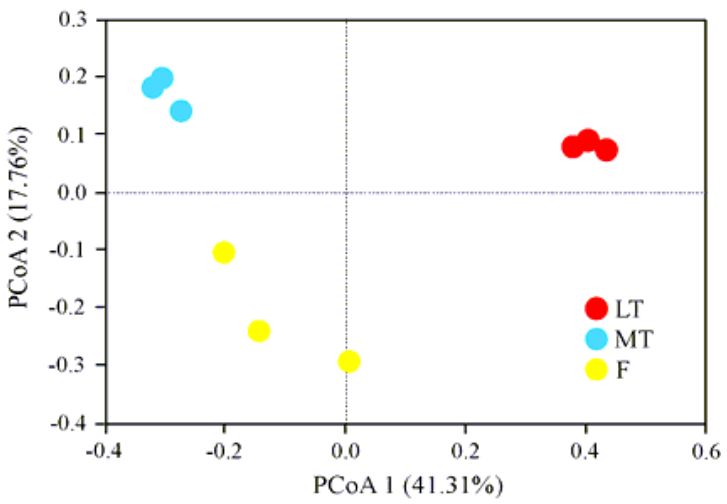

(c)

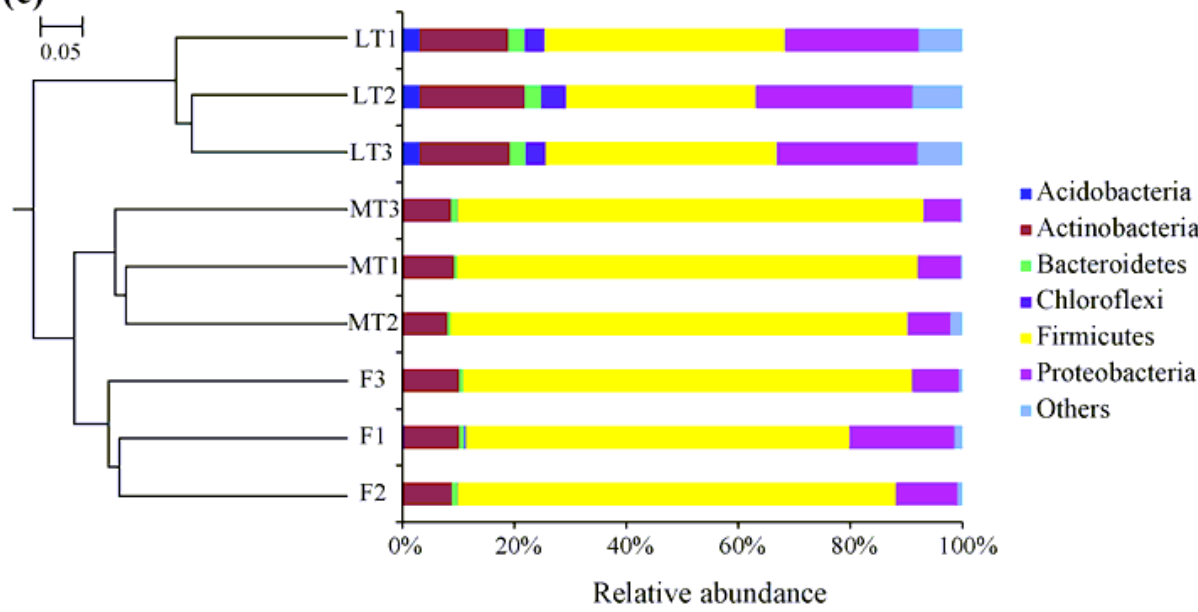

(e)

Exclusive and Shared OTUs

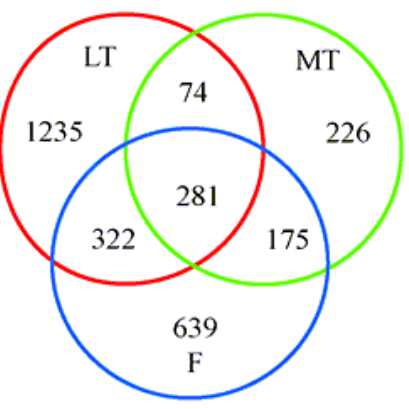

Exclusive and Shared Reads
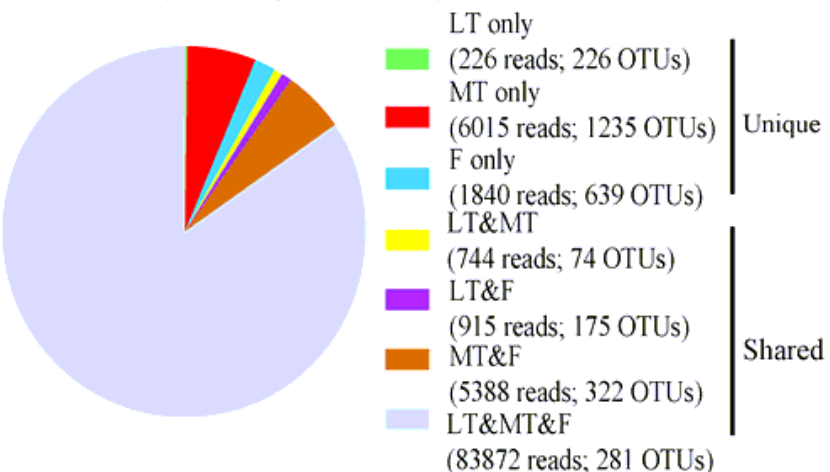

(d)
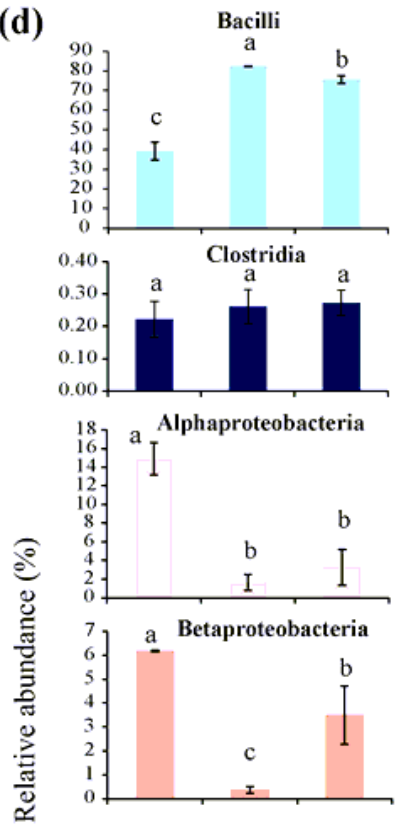

2.0 a Deltaproteobacteria
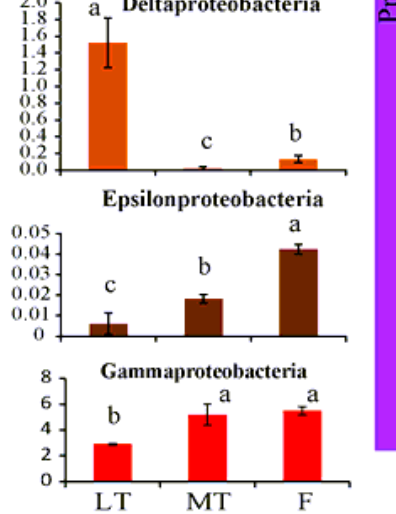

Figure 1

Comparison of alpha diversity indices and composition of bacterial communities on rock surfaces from less and more altered slate rocks (LT and MT groups respectively) from the triggering area and slate rock from flowing area ( $F$ group) of debris flow in Dongchuan district of Kunming based on 16S rRNA gene MiSeq sequencing analysis. (A) Changes in Faith's index of phylogenetic diversity (PD), number of unique operational taxonomic units (OTUs), Shannon index, and Chao1 index across different groups. Random 
selections of 11,000 sequences per rock sample were used for calculation of diversity indices. (B) A dendrogram was constructed by using UPGMA, and shown together with the relative abundances of the dominant bacterial phyla. Percentage bootstrap values obtained from 1000 trials are shown on branches. (C) The distribution of dominant bacterial classes. (D) Principal Coordinates Analysis (PCoA) plot depicts the Bray-Curtis distance of bacterial communities in LT, MT, and F groups. Error bars denote standard errors, while different lowercase letters above SE bars represent significant differences according to Tukey's Honestly Significant Difference (HSD) post-hoc test $(P<0.05)$. (E) Venn diagrams showing the distribution of OTUs in different rock samples. Left panel: Venn diagram of exclusive and shared nonsingleton OTUs (at $\geq 97 \%$ sequence identity) in different groups. In total, 2,952 OTUs were present across samples. Right panel: number of $16 \mathrm{~S}$ rRNA gene sequences in each of the indicated segments of the Venn diagram. Totally, 99,000 sequences were present across samples.

(a)

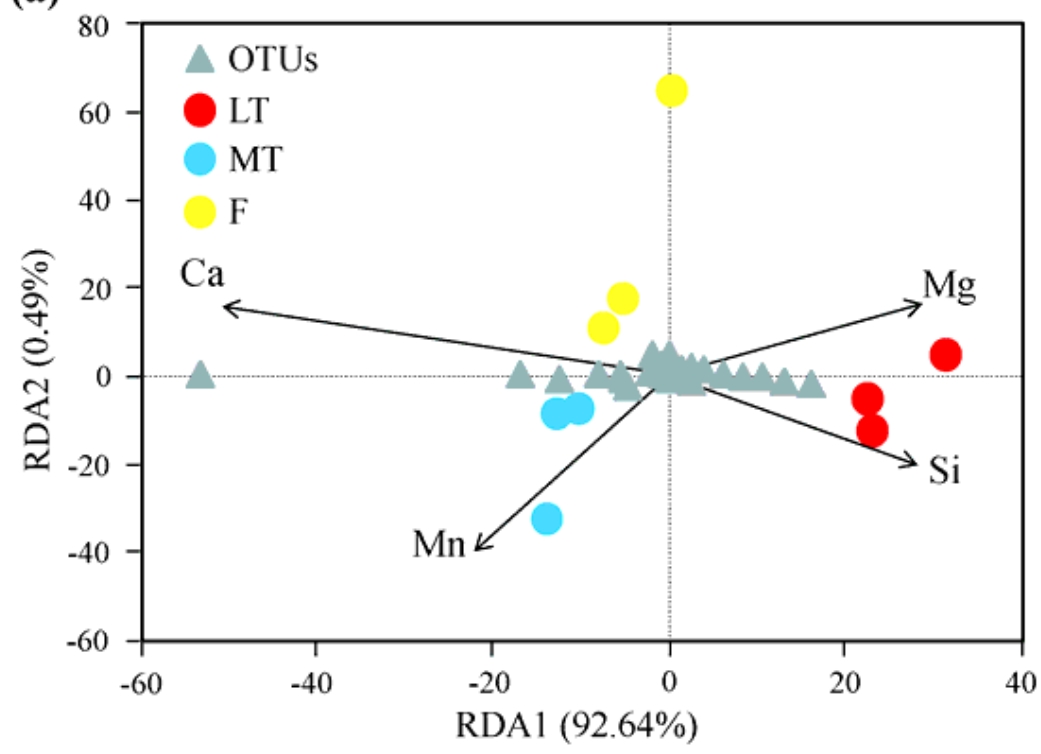

(b)

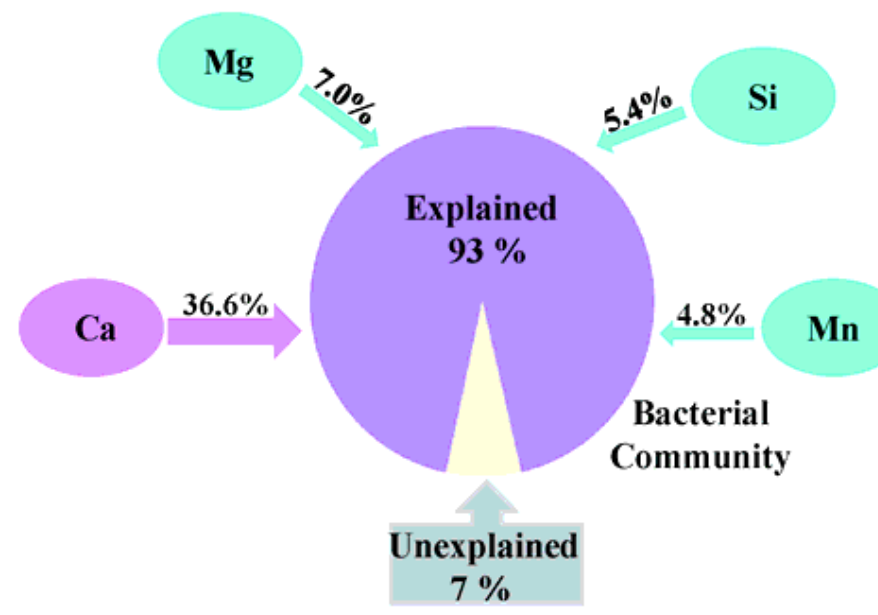

Figure 2

Redundancy analysis (RDA) plot depicting the correlation between bacterial communities and rock properties $(A)$ and the percentage of variance explained by studied rock properties selected by RDA model (B). The proportion explained by $\mathrm{Ca}, \mathrm{Mg}, \mathrm{Si}$, and $\mathrm{Mn}$ were presented. 
(a)

\section{Organic aicd production}

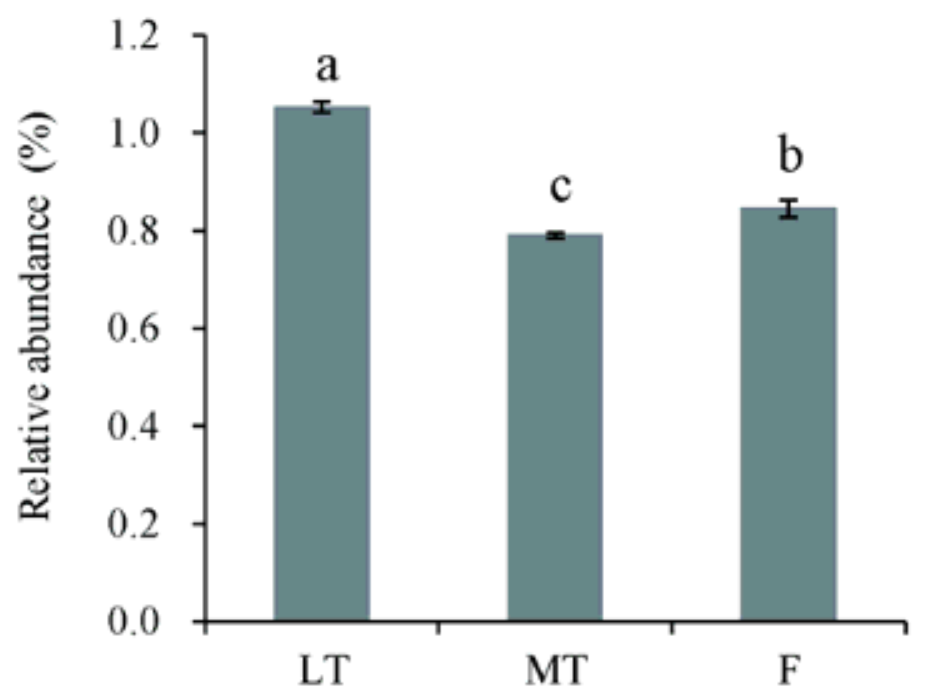

(c)

Biosynthesis of siderophore

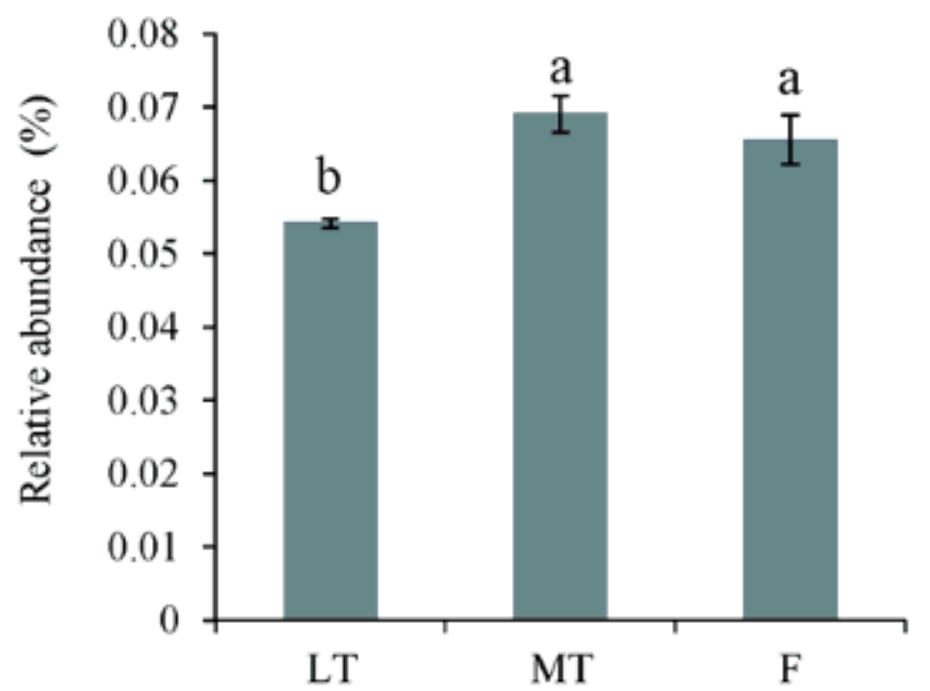

(b)

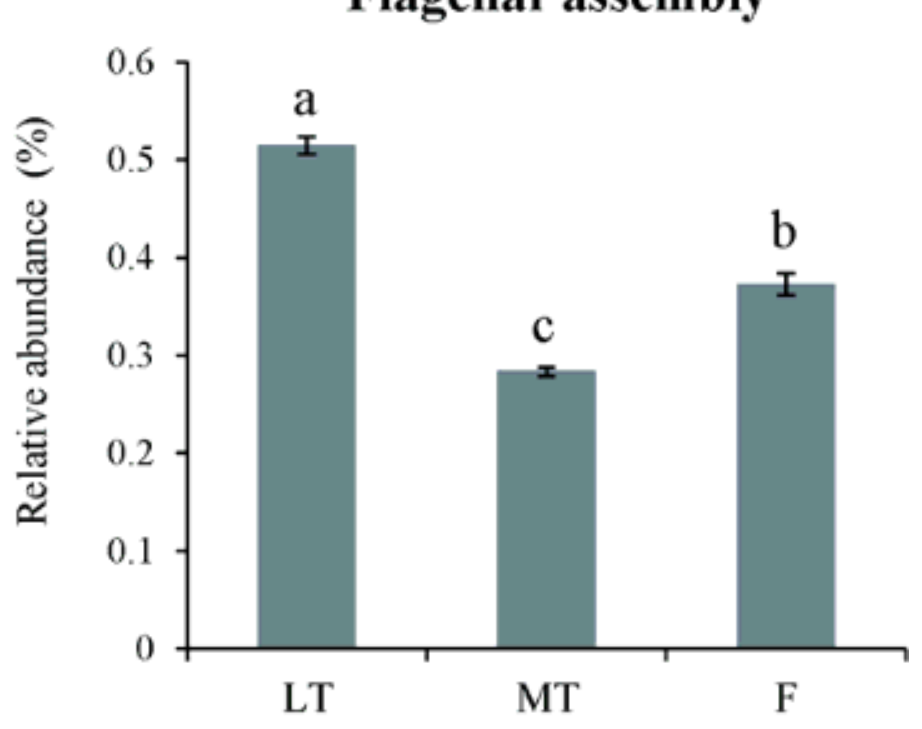

(d)

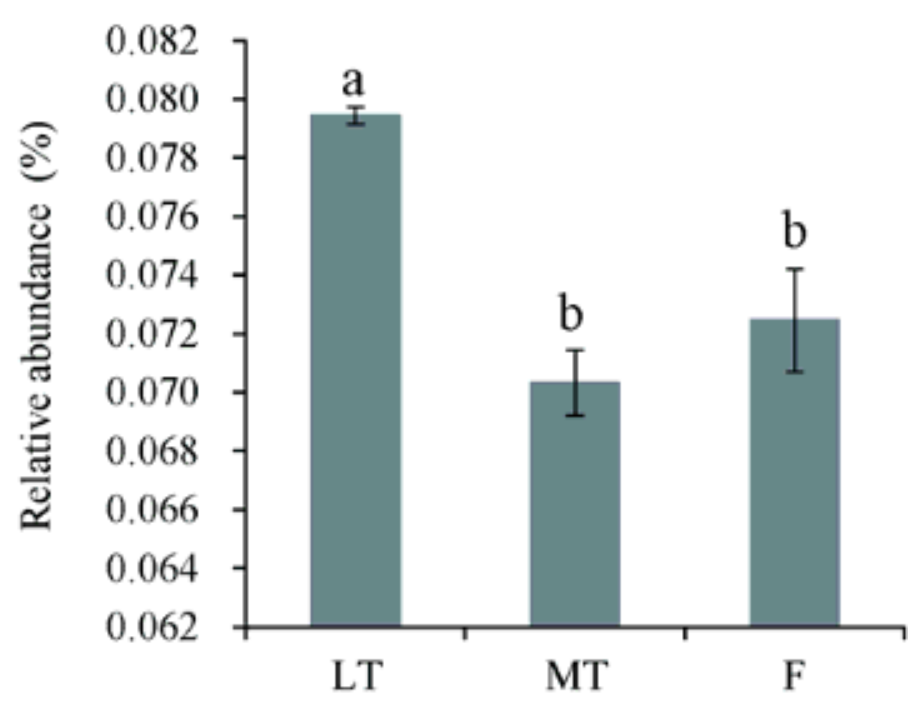

Figure 3

Inferred microbiome functions associated with rock weathering including the production of organic acids (including level 3 KEGG Orthology groups of citrate cycle, glycolysis, and pyruvate metabolism, which were involved in carbohydrate metabolism) (A), flagellar assemble (KEGG level 3) (B), biosynthesis of siderophores (KEGG level 3) (C), and carbonic anhydrase (D) of bacterial communities inhabiting rock surfaces from groups $\mathrm{LT}, \mathrm{MT}$, and $\mathrm{F}$. The relative abundance of each genetic family (KO) indicates the ratio of the estimated genomic copy number of each $\mathrm{KO}$ to the genomic copy number of all KOs. Error bars denote standard error, while different letters above error bars represent significant differences from Tukey's HSD comparisons $(P<0.05)$. 


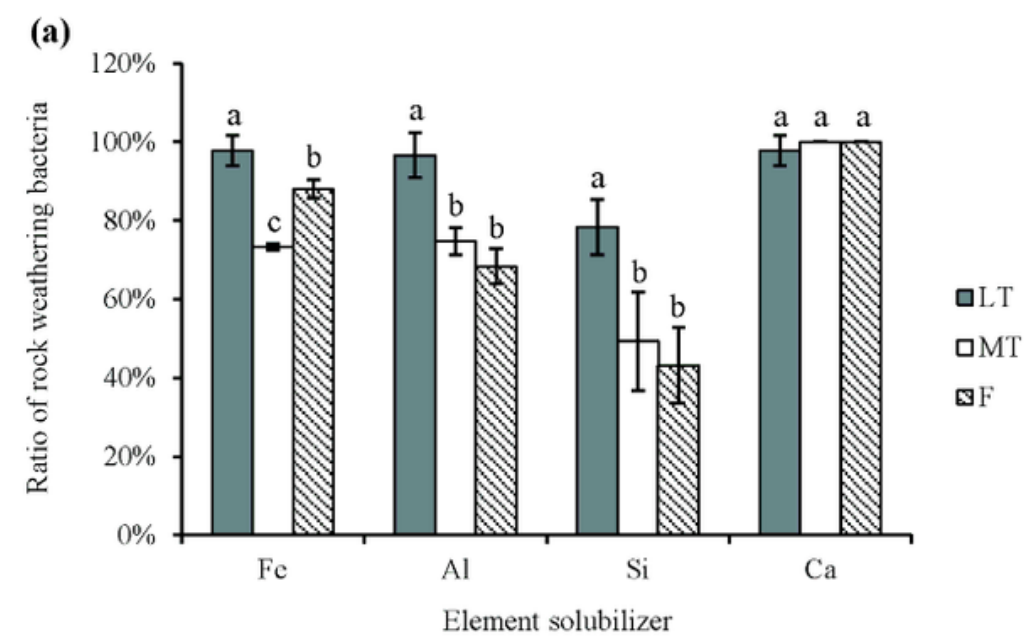

(b)
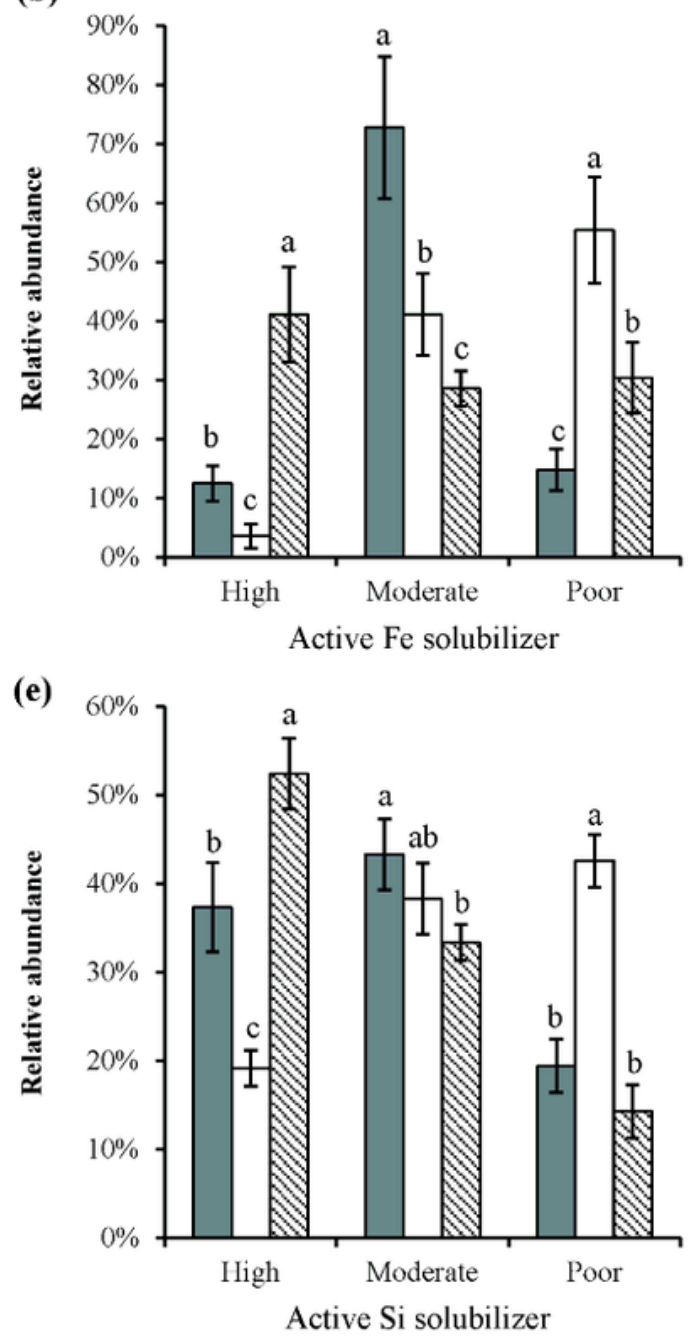

(c)
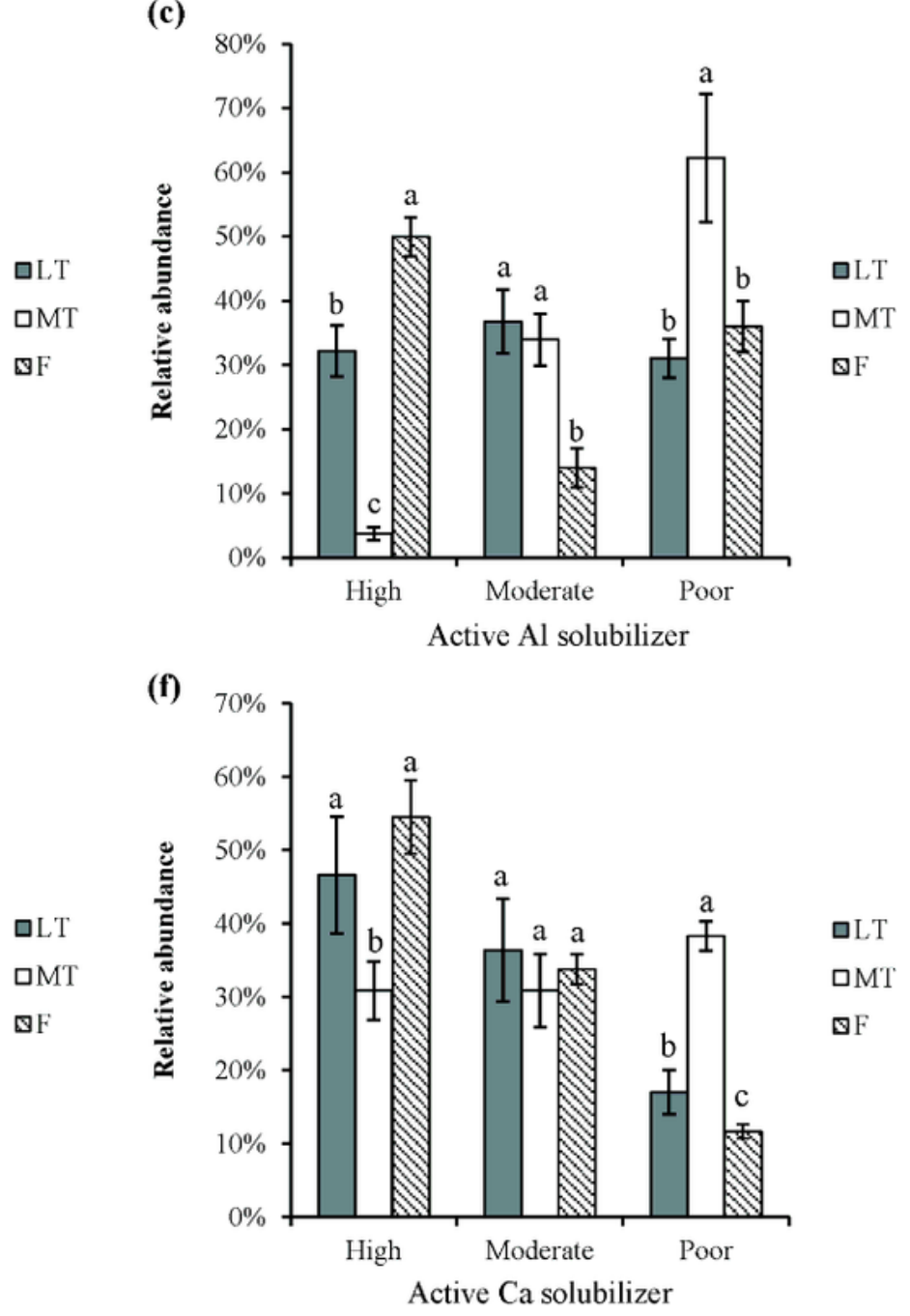

Figure 4

Influence of bacteria isolated from rock surface on the elements released from potash trachyte. The raio of bacterial strain that significantly enhance the release of $\mathrm{Fe}, \mathrm{Si}, \mathrm{Al}$, and $\mathrm{Ca}$ from slate isolated from groups LT, MT, and F, respectively (A). Proportion of the highly, moderately, and poorly effective $\mathrm{Fe}(\mathrm{B}), \mathrm{Si}$ (C), Al (D) and Ca (E) solubilizers isolated from groups LT, MT, and F respectively. Error bars indicate standard errors $(n=3)$, while different lowercase letters above error bars represent significant differences 
according to Tukey's Honestly Significant Difference (HSD) post-hoc test $(P<0.05)$. A total of 248 bacterial strains were tested for their ability to weathering slate.

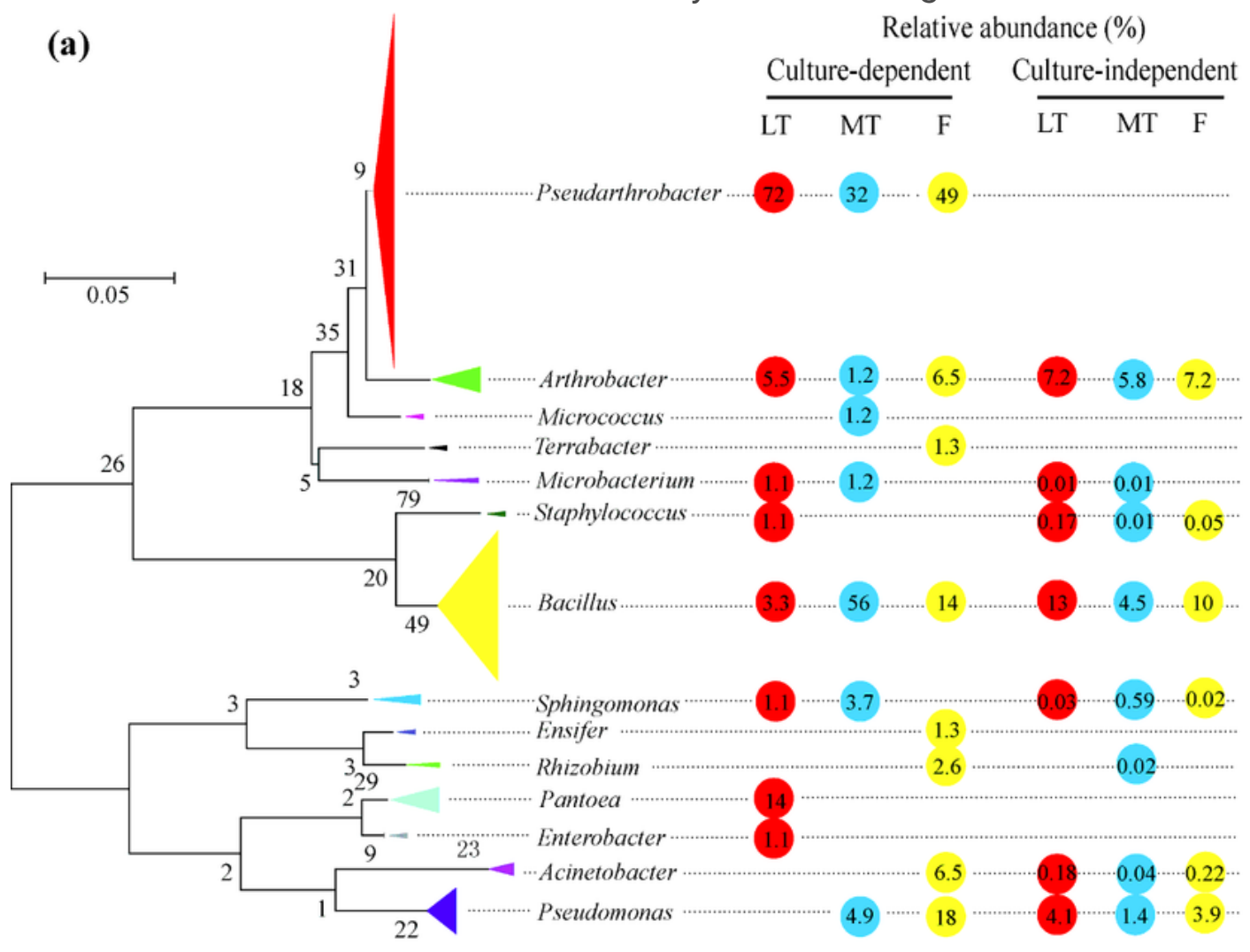

(b)
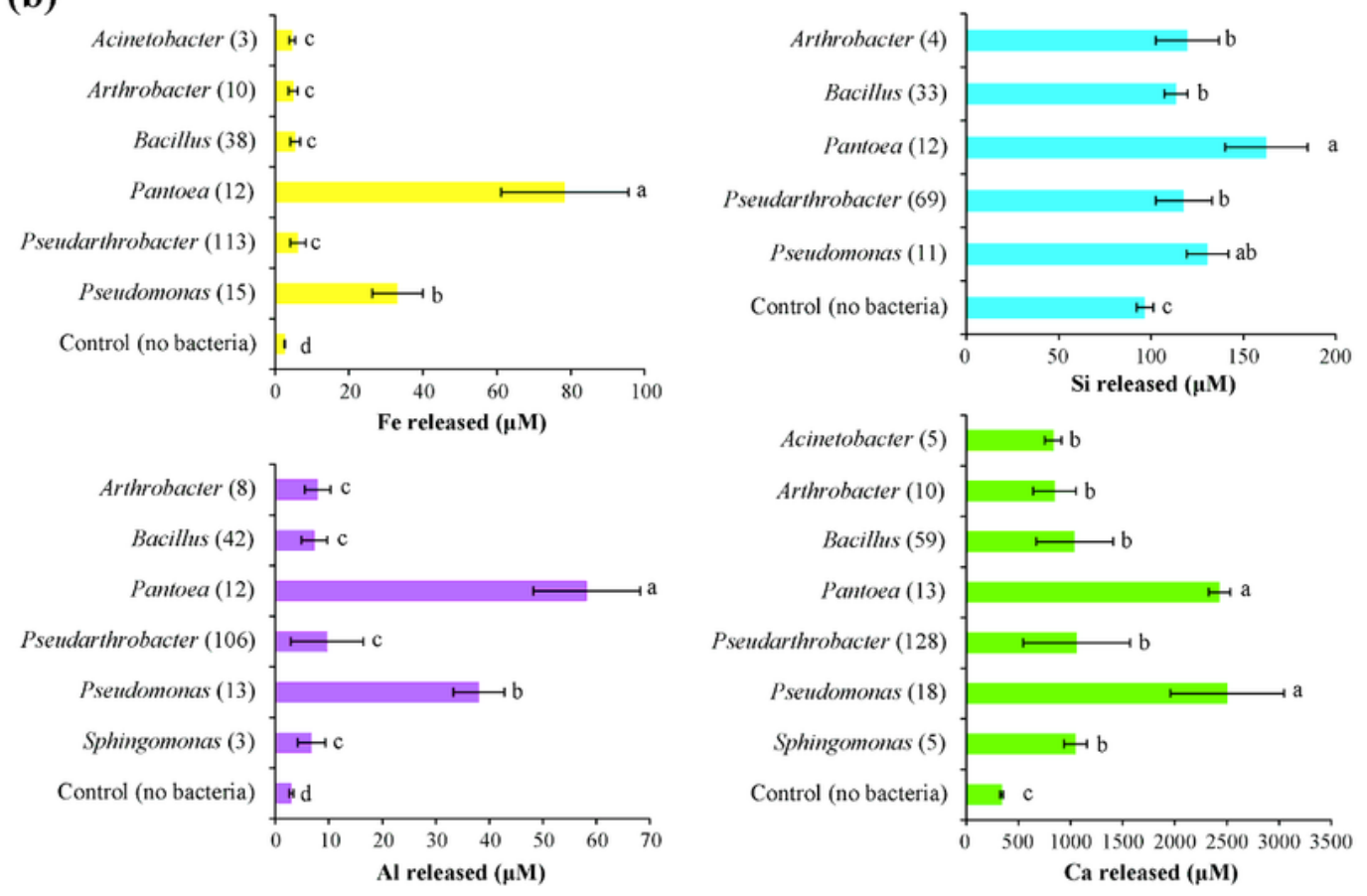

Figure 5

Comparison of the distribution and their rock-weathering ability of bacterial genera. A. Taxa and lineages of cultivable rock-weathering bacterial populations clustering, and the relative abundances of these genera in different groups based on both cultivation-dependent and -independent analyses. Bootstrap 
values (1,000 replicates) more than 50 are given. A total of 248 bacterial strains were identified based on 16S rRNA gene sequences based on the culture-dependent method. B. Relationship between the mean concentrations of $\mathrm{Fe}, \mathrm{Si} \mathrm{Al}$, and $\mathrm{Ca}$ in the cultural medium and the genus-level classification of the bacterial strains. The number of bacterial strains isolated per genus is given in parenthesis. For genera with a minimum of 3 bacterial strains identified, a one-way ANOVA was performed $(P=0.05)$. Bars marked with the same letters are not significantly different.

\section{Supplementary Files}

This is a list of supplementary files associated with this preprint. Click to download.

- renamedf6483.docx 